\title{
Associations of serotonin transporter gene promoter polymorphisms and monoamine oxidase A gene polymorphisms with oppositional defiant disorder in a Chinese Han population
}

Chang-Hong Wang ${ }^{1 *+}$, Qiu-Fen Ning ${ }^{1+}$, Cong Liu ${ }^{1+}$, Ting-Ting Lv' ${ }^{1}$, En-Zhao Cong ${ }^{1}$, Jing-Yang Gu ${ }^{1}$, Ying-Li Zhang ${ }^{1}$, Hui-Yao Nie ${ }^{1}$, Xiao-Li Zhang ${ }^{1}$, Yan Li ${ }^{2}$, Xiang-Yang Zhang ${ }^{3}$ and Lin-Yan Su ${ }^{4^{*}+}$

\begin{abstract}
Background: Oppositional defiant disorder (ODD) is a behavioral disorder that mainly refers to a recurrent pattern of disobedient, defiant, negativistic and hostile behaviors toward authority figures. Previous studies have showed associations of serotonin transporter (5-HTT) and monoamine oxidase A (MAOA) with behavioral and psychiatric disorders. The purposes of this study were to investigate the potential association of 5-HTT gene promoter polymorphism (5-HTTLPR) and MAOA gene polymorphism with susceptibility to ODD in a Han Chinese school population.

Methods: The 5-HTTLPR gene polymorphism and the MAOA gene polymorphism were genotyped in a case-control study of 257 Han Chinese children (123 ODD and 134 healthy controls).

Results: There was significant difference in the allele distribution of 5 -HTTLPR $\left(X^{2}=7.849, P=0.005\right)$ between the ODD and control groups. Further, there were significant differences in genotype $\left(X^{2}=5.168, P=0.023\right)$ and allele distributions $\left(X^{2}=10.336, P=0.001\right)$ of the MAOA gene polymorphism that is variable-number tandem repeat (MAOAuVNTR) between two groups. Moreover, there were significant differences in genotype $\left(X^{2}=4.624, P=0.032\right)$ and allele distributions ( $X^{2}=9.248, P=0.002$ ) of MAOA-uVNTR only in the male ODD and healthy groups.
\end{abstract}

Conclusions: Our results suggest that 5-HTTLPR and MAOA-uVNTR gene variants may contribute to susceptibility to ODD. Further, MAOA-uVNTR gene polymorphism may play a role in susceptibility to ODD only in male children.

Keywords: Oppositional defiant disorder, Serotonin transporter, Monoamine oxidase A, Gene polymorphism

\footnotetext{
*Correspondence: wangchdr@163.com; xysulinyan@126.com

${ }^{\dagger}$ Chang-Hong Wang, Qiu-Fen Ning, Cong Liu and Lin-Yan Su contributed equally to this work

${ }^{1}$ Department of Psychiatry, The Second Affiliated Hospital of Xinxiang

Medical University (Psychiatric Hospital of Henan Province China), Jianshe

Road 388, Xinxiang 453002, Henan, China

${ }^{4}$ Department of Psychiatry, Mental Health Institute, Second Xiangya

Hospital of Central South University, Changsha 410011, China

Full list of author information is available at the end of the article
} (http://creativecommons.org/licenses/by/4.0/), which permits unrestricted use, distribution, and reproduction in any medium, provided you give appropriate credit to the original author(s) and the source, provide a link to the Creative Commons license, and indicate if changes were made. The Creative Commons Public Domain Dedication waiver (http://creativecommons.org/ publicdomain/zero/1.0/) applies to the data made available in this article, unless otherwise stated. 


\section{Background}

Oppositional defiant disorder (ODD), a common childhood disorder, is a behavioral disorder that mainly refers to a recurrent pattern of disobedient, defiant, negativistic and hostile behavior toward authority figures [1-3]. Even mild stimulation can lead to impulsive actions or intense emotional reaction from the children with ODD, since they may have trouble in controlling their temper. Accordingly, ODD is also deemed as a disorder of emotional adjustment [4]. ODD can lead to a large number of negative outcomes that are dreadful to their lifetime, such as anxiety, some psychiatric problems, unemployment or even delinquency [5].

Nowadays, ODD is one of the leading reasons for referral to youth mental health services [6]. A survey [7] based on Diagnostic and Statistical Manual of Mental Disorders-IV-Text Revision (DSM-IV-TR) from an Asian country showed that the morbidity for ODD is $2 \%$ to $16 \%$, with the ODD prevalence of $3.87 \%$ in the Turkish children [8]. As a result, the disorder has now become a hot spot of research in the field of children's mental health. Unfortunately, the pathological mechanisms of ODD are still unclear yet. The previous studies have indicated that ODD possesses some of its own characteristics such as moderate heritability, substantially stable over time [9], and familial clustering [1], suggesting an underlying genetic component.

Serotonin (5-HT) is one of crucial neurotransmitters that controls the behaviors of the individuals, such as appetite, locomotion, aggression and attention. It has been demonstrated that deficiency in the 5-HT functions has some serious effects on increased pain sensation, anxiety, aggression, attention deficit hyperactivity disorder (ADHD) symptoms [10], and even impulsivity, which are common characteristics of substance abuse [11, 12], ODD and personality disorder $[13,14]$. Early studies have reported that impulsive attacking activities, and antisocial behaviors, as well as other "de-inhibition" behaviors, are closely related to dysfunction of the brain 5-HT system $[15,16]$. A strong relationship between impulsive aggression and low cerebrospinal fluid 5-HT has been reported in the previous study [17]. It appears that ODD is also associated with dysfunctions of the 5 -HT system $[13,14]$.

Furthermore, the related enzymes, such as monoamine oxidase A (MAOA) can regulate the synthesis, transfer, and decomposition of 5-HT, and may also play an important role in the development of ODD. Accumulating evidence has demonstrated the association between ADHD and 5-HT, 5-HTT or MAOA [18]. Meanwhile, it was reported that the serotonin transporter gene promoter polymorphism (5-HTTLPR) was associated with borderline personality disorder in young people [19], and with antisocial personality disorder [20]. On the other hand, MAOA genotype was found to be associated with impulsive and antisocial personality traits in alcoholic men [21]. MAOA also contributed to the pathogenesis of aggression [22, 23] and antisocial personality [24]. A previous study reported a $30 \mathrm{bp}$ variable number of tandem repeats (VNTR) polymorphism located in the upstream MAOA promoter region (MAOA-uVNTR) [25]. The VNTR alleles consist of 2 repeats, 3 repeats, 3.5 repeats, 4 repeats, or 5 repeats. Alleles with 3.5 or 4 copies of the repeat sequence were associated with higher MAOA gene activity (MAOA-H), while alleles with 2, 3 or 5 copies of the repeat sequence were associated with lower gene activity (MAOA-L), demonstrating that this polymorphism may strongly affect the transcriptional efficiency of MAOA gene, and may be regarded as a functional genetic marker for MAOA gene [23].

In terms of the associations of 5-HTTLPR and MAOAUVNTR with behavioral and psychiatric disorders in previous studies, it would be of interest to examine the association between 5-HTTLPR or MAOA-uVNTR and ODD, which, to our best knowledge, has not been investigated. Therefore, the present study was designed to investigate the potential association of 5-HTTLPR or MAOA-uVNTR with susceptibility to ODD in a Han Chinese school population.

\section{Materials and methods}

The present study was designed in compliance with the Helsinki Declaration and was approved by the Ethical Committee of the Second Affiliated Hospital, Xinxiang Medical College, Henan Province. Written informed consent was obtained from all subjects and their parents.

\section{Study participants}

We used random group sampling method to collect samples from 2000 Chinese Han pupil in Nanyang City, Henan Province, China, between 2007 and 2009. All their teachers completed Conners Teachers Rating Scale. In order to conform to the diagnostic criteria, a chief physician and resident physician had an interview with one or both parents as well as the teachers, and then made a diagnosis of ODD based on Diagnostic and Statistical Manual of Mental Disorders-IV (DSM-IV) diagnostic criteria. We also recruited the healthy control subjects from the same primary school as control group.

The exclusion criteria included: (1) intelligence quotient (IQ) $<70$ (IQ criteria was based on Raven's Progressive Matrices); (2) low body mass index (BMI, $<18.5 \mathrm{~kg} /$ $\mathrm{m}^{2}$ ); and (3) any physical diseases, ADHD or Conduct disorder (CD) symptoms, as well as other mental illnesses. 
Totally, we recruited 123 ODD (male/female $=70 / 53$ ) with an average age of $10.4 \pm 1.8$ years, as well as 134 healthy controls (male/female $=66 / 68$ ) with an average age of $10.1 \pm 2.0$ years. They matched on age $(t=1.969$, $P=0.209)$ and gender $\left(x^{2}=1.509, P=0.219\right)$.

\section{Genotyping}

$5 \mathrm{ml}$ peripheral blood samples from cubital vein of each subject were drawn into vacutainer tubes containing the anticoagulant ethylenediaminetetracetic acid (EDTA) between 8:00 and 9:00 am after an overnight fasting. Blood samples were stored at $-70{ }^{\circ} \mathrm{C}$ until being assayed.

Genomic DNA was isolated from the whole blood using a standard phenol-chloroform technique (the human leukocyte DNA extraction kit from TianGen Biotech), in accordance with the manufacturer's instructions.

The polymorphism of the 5-HTTLPR was genotyped using a polymerase chain reaction (PCR). Primers for the PCR were designed as described in a previous study [26]. The PCR products were assayed using gel electrophoresis and genotype analysis.

The PCR conditions for polymorphisms of 5-HT gene were as follows: DNA was denatured at $95{ }^{\circ} \mathrm{C}$ for $4 \mathrm{~min}$ and subjected to 34 cycles of $40 \mathrm{~s}$ denaturation at $94{ }^{\circ} \mathrm{C}$, $40 \mathrm{~s}$ annealing at $63{ }^{\circ} \mathrm{C}, 40 \mathrm{~s}$ extension at $72{ }^{\circ} \mathrm{C}$, and a final extension step of $72{ }^{\circ} \mathrm{C}$ for $10 \mathrm{~min}$. The PCR products were then analyzed on $7 \%$ polyacrylamide gels that were stained with ethidium bromide. Product sizes for cleaved products were: L (528 base pairs) and S (484 base pairs).

The MAOA-uVNTR was genotyped as described by Manor et al. [27]. The MAOA-uVNTR genotypes were divided into three groups: $3 / 3$ (low activity allele), $3 / 4$ and 4/4 (high activity alleles) [28]. Primers for the PCR were designed as described in a previous study [28]. The PCR conditions for MAOA gene were as follows: DNA was denatured at $95^{\circ} \mathrm{C}$ for 4 min and subjected to 34 cycles of $40 \mathrm{~s}$ denaturation at $94{ }^{\circ} \mathrm{C}, 40 \mathrm{~s}$ annealing at $54{ }^{\circ} \mathrm{C}, 40 \mathrm{~s}$ extension at $72{ }^{\circ} \mathrm{C}$, and a final extension step of $72{ }^{\circ} \mathrm{C}$ for $10 \mathrm{~min}$.
Table 2 Distribution of polymorphisms of the MAO-A gene in the ODD group and controls

\begin{tabular}{lcccc}
\hline Genotype & $\mathbf{3 / 3}(\%)$ & $\mathbf{3 / 4}$ and $\mathbf{4 / 4}(\%)$ & $\mathbf{X}^{\mathbf{2}}$ & $\boldsymbol{P}$ \\
\hline Male & & & & \\
ODD $(n=70)$ & $13(18.6)$ & $57(81.4)$ & 4.624 & $0.032^{*}$ \\
Controls $(n=66)$ & $23(34.8)$ & $43(65.2)$ & & \\
OR(95\%Cl) & $0.43(0.94-0.19)$ & $2.35(1.07-5.15)$ & & \\
Female & & & & \\
ODD $(n=53)$ & $5(9.4 \%)$ & $48(90.6 \%)$ & 1.664 & 0.197 \\
Controls $(n=68)$ & $12(17.6 \%)$ & $56(82.4 \%)$ & & \\
OR(95\%Cl) & $0.49(0.16-1.48)$ & $2.06(0.68-6.26)$ & & \\
Alleles & & & & \\
Female & & & & \\
ODD $(n=53)$ & $10(9.4 \%)$ & $96(90.6 \%)$ & 3.328 & 0.068 \\
Controls $(n=68)$ & $24(17.6 \%)$ & $112(82.4 \%)$ & & \\
\hline
\end{tabular}

$\mathrm{df}=1,{ }^{*} P<0.05$

\section{Statistical analysis}

PASW Statistics 13.0 software (SPSS Inc., Chicago, IL, USA) was used to analyze the differences in allele and genotype frequencies between the two groups, with Chi squared test for categorical variables.

We used Chi square $\left(\mathrm{X}^{2}\right)$ goodness-of-fit test to test the deviation from the Hardy-Weinberg equilibrium (HWE) in cases and controls separately according to previous study [29].

The level of significance was set at $P=0.025$ after Bonferroni correction.

\section{Results}

Hardy-Weinberg genetic equilibrium testing

The genotypic distributions of the 5-HTTLPR were in agreement with the HWE in both the ODD $\left(\chi^{2}=1.3831\right.$, $\mathrm{df}=1, P>0.05)$ and control groups $\left(\chi^{2}=1.4758, \mathrm{df}=1\right.$, $P>0.05)$. The genotypic distributions of MAOA-uVNTR were in agreement with the HWE in females, in both the ODD $\left(\chi^{2}=0.422, \mathrm{df}=1, P=0.516\right)$ and control groups $\left(x^{2}=0.107, \mathrm{df}=1, P=0.743\right)$. The genotype and allele frequencies of HTTLPR and MAOA-uTNTR in the ODD and control groups are shown in Tables 1 and 2.

Table 1 Distribution of polymorphisms of the 5-HTTLPR gene in the ODD group and controls

\begin{tabular}{|c|c|c|c|c|c|c|c|c|c|}
\hline & \multicolumn{3}{|l|}{ Genotype (\%) } & \multirow[t]{2}{*}{$x^{2}$} & \multirow[t]{2}{*}{$P$} & \multicolumn{2}{|l|}{ Alleles (\%) } & \multirow[t]{2}{*}{$x^{2}$} & \multirow[t]{2}{*}{$P$} \\
\hline & LL & LS & SS & & & $\mathbf{L}$ & $\mathrm{S}$ & & \\
\hline $\operatorname{ODD}(n=123)$ & $7(5.7)$ & $10(8.1)$ & $106(86.2)$ & 5.559 & 0.062 & $24(9.8)$ & $222(90.2)$ & 7.849 & $0.005^{*}$ \\
\hline Controls $(n=133)$ & $15(11.3)$ & $19(14.3)$ & $99(74.4)$ & & & $49(18.4)$ & $217(81.6)$ & & \\
\hline OR $(95 \%$ Cl) & $0.44(0.17-1.11)$ & $0.49(0.22-1.11)$ & 1.00 & & & $0.48(0.28-0.80)$ & $2.09(1.24-3.52)$ & & \\
\hline
\end{tabular}

$\mathrm{df}=1,{ }^{*} P<0.05$ 
Comparison of 5-HTTLPR genotype and allele frequencies between ODD and control groups

Although there were no significant differences in the 5-HTTLPR genotype distributions between the ODD and control groups $\left(X^{2}=5.559, P=0.062\right)$, there were statistically significant differences in the allele distributions $\left(X^{2}=7.849, P=0.005\right)$. With the dominant model (SS VS LL-LS), the genotype distributions displayed significant differences between the case and control groups $\left(\chi^{2}=5.559, P=0.062\right.$; OR $=0.58,95 \%$ CI $\left.0.44-0.78\right)$.

\section{Comparison of MAOA-uVNTR genotype and allele frequencies between ODD and control groups}

There were significant differences in the genotype $\left(X^{2}=5.168, P=0.023\right)$ and allele distributions $\left(\chi^{2}=10.336, P=0.001\right)$ of MAOA-uVNTR between the ODD and control groups. Further, there were also significant differences in the allele $\left(X^{2}=9.248, P=0.002\right)$ and genotype $\left(X^{2}=4.624, P=0.032\right)$ distributions between the male ODD and male control groups, but no significant differences in genotype $\left(X^{2}=1.664, P=0.197\right)$ and allele distributions $\left(X^{2}=3.328, P=0.068\right)$ between the female ODD and female control groups.

\section{Discussion}

To our knowledge, this is the first study to confirm an association between the 5-HTTLPR or MAOA-uVNTR polymorphism and ODD in a Chinese Han population.

Although no significant differences were observed in the 5-HTTLPR genotype frequencies between the ODD and control groups, the allele frequencies of the two groups showed significant differences. The significantly lower $\mathrm{L}$ allele frequency, but the significantly higher $\mathrm{S}$ allele frequency was noted in the ODD children compared with the control children. Thus, the $\mathrm{S}$ allele of 5-HTTLPR may increase the risk for ODD, whilst the L allele may be protective. These results are consistent with previous reports showing that the $\mathrm{S}$ allele was associated with violent suicide [30] and violence, ADHD [31], PTSD, alcohol dependence, and conduct problems [32], but not with personality traits [33]. However, a study showed that the L allele of 5-HTTLPR might increase the risk of attacking behaviors in the Alzheimer's patients [34], which is contrary to our findings. The reasons for the discrepancies between these 2 studies are unclear, but may be related to different study subjects, i.e., senior patients in the Alzheimer's study versus children in our ODD study.

The MAOA-uVNTR genotype and allele distributions were significantly different between the ODD and control groups. Further analysis showed that the highactivity allele of MAOA-uVNTR may increase the risk for ODD in children, whilst the low-activity allele may be a protective factor, which are consistent with previous studies showing that MAOA-uVNTR was associated with impulsive behaviors and alcohol dependence [35], aggressive behaviors [36, 37] and suicide attempts in patients with major depressive disorder [38]. In contrast, some studies [39-41] indicated that boys suffering from abuse with the low-activity allele of MAOA-uVNTR were at higher risk of developing antisocial behaviors. Another study found that aggressive behaviors were also associated with the low-activity allele of MAOA-uVNTR [42]. Additionally, some reports showed no correlation between MAOA-uVNTR and impulsive behavior [43, 44]. The reasons for the discrepancies between these studies may be related to either the different methods adopted by different researchers, or the difference in the number of study samples.

Violence is thought to be a male trait, which may be controlled by a gene on the Y chromosome. However, the gene that controls the trait and produces MAOA can only be found on the X chromosome [25]. There are two $\mathrm{X}$ chromosomes in females, and only one $\mathrm{X}$ chromosome and one $\mathrm{Y}$ chromosome in males. To determine whether sex influenced the MAOA-uVNTR results, we specifically performed further statistical analysis on the male ODD versus male control groups or on the female ODD versus control groups separately, showing the genotype and allele distributions of MAOA-uVNTR were significantly different only between the male ODD and control groups. This indicated that MAOA-uVNTR was only associated with male ODD patients. Our results demonstrated that the high-activity allele of MAOA-uVNTR may increase the risk for male ODD. Taken together, these results suggested that MAOA-uVNTR gene polymorphism may be susceptible for ODD in male children, which is consistent with to a previous study showing association between MAOA-VNTR and aggressive behavior in males [45].

The samples in this study were mainly collected from local schools in Nanyang City, Henan Province, China. Thus, the subjects from the single geographical location may have bias for the results. Moreover, there is only the limited sample size in the current study, with low statistical power. Thus, the findings in our present study remain preliminary and future studies with an increased number of samples from the multiple locations will be needed.

\section{Conclusion}

The $\mathrm{S}$ allele of 5-HTTLPR may increase the risk for ODD in Chinese Han children, whereas the $\mathrm{L}$ allele may be a protective factor. The high-activity allele of MAOA-uVNTR may increase the risk for ODD in Chinese Han male children. 


\begin{abstract}
Abbreviations
ODD: oppositional defiant disorder; 5-HTT: serotonin transporter; MAOA: monoamine oxidase $\mathrm{A} ; 5-\mathrm{HTTLPR}$ : serotonin transporter gene promoter polymorphism; MAOA-UVNTR: monoamine oxidase A- untranslated variable nucleotide tandem repeat; PCR: polymerase chain reaction; DSM-IV-TR: Diagnostic and Statistical Manual of Mental Disorders-IV-Text Revision; ADHD: attention-deficit/hyperactivity disorder; MAOA-H: higher MAOA gene activity; MAOA-L: lower MAOA gene activity; DSM-IV: Diagnostic and Statistical Manual of Mental Disorders-IV; IQ: intelligence quotient; BMI: body mass index; CD: conduct disorder; EDTA: ethylenediaminetetracetic acid; ANOVA: one-way analysis of variance; HWE: Hardy-Weinberg equilibrium.
\end{abstract}

\section{Authors' contributions}

CHW, QFN, and CL contributed equally for this study and are both considered as first authors, they created the conception of the study and the experimental paradigm, managed the acquisition of the data, analyzed and interpreted the data. TTL, EZC, JYG, YLZ, HYN, and XLZ wrote the first draft together. YL, $X Y Z, C H W$, and LYS thorough read this manuscript and final approval of the version to be published. CHW and LYS are the corresponding authors and have contributed equally to this work. All authors read and approved the final manuscript.

\section{Author details \\ 1 Department of Psychiatry, The Second Affiliated Hospital of Xinxiang Medical University (Psychiatric Hospital of Henan Province China), Jianshe Road 388, Xinxiang 453002, Henan, China. ${ }^{2}$ Department of Child and Adolescent, Public Health College, Zhengzhou University, Kexue Road 100, Zhengzhou 450001, Henan, China. ${ }^{3}$ Department of Psychiatry and Behavioral Sciences, UT Hou- ston Medical School, The University of Texas Health Science Center at Houston, 1941 East Road, Houston, TX 77054, USA. ${ }^{4}$ Department of Psychiatry, Mental Health Institute, Second Xiangya Hospital of Central South University, Chang- sha 410011 , China.}

\section{Acknowledgements}

This work was supported by the support project for the Disciplinary group of Psychology and Neuroscience, Xinxiang Medical University, and Henan Key Laboratory of Biological Psychiatry. We warmly thank the children and their parents who kindly took part in this research, as well as the schools and the teachers who agreed to collaborate in this study.

\section{Competing interests}

The related authorities and the authors declare that they all have no competing interest. The authors declare that the research was conducted in the absence of any commercial, financial (and non-financial) relationships that could be construed as a potential competing interests.

\section{Consent for publication}

1. We have obtained the informed consent for publication from the children's parents or legal guardian. 2. All of the authors agreed to publish this manuscript.

\section{Fundings}

This work was supported by the support project for the Disciplinary group of Psychology and Neuroscience, Xinxiang Medical University; this work was supported by grants from the Medical Technology Foundation of Henan Province [Grant Numbers 142300410025, 112102310211], Scientific Research Fund of Xinxiang Medical University [Grant Number 2013ZD117] and Ministry of Health research fund projects in China [Grant Number 20090103]. Henan Provincial Department of Science and Technology Research Project [Grant Number 102101310400].

\section{Publisher's Note}

Springer Nature remains neutral with regard to jurisdictional claims in published maps and institutional affiliations.

Received: 23 April 2017 Accepted: 11 August 2018

Published online: 20 August 2018

\section{References}

1. Riley M, Ahmed S, Locke A. Common questions about oppositional defiant disorder. Am Fam Physician. 2016;93(7):586-91.

2. Frick PJ, Nigg JT. Current issues in the diagnosis of attention deficit hyperactivity disorder, oppositional defiant disorder, and conduct disorder. Annu Rev Clin Psychol. 2012;8:77-107. https://doi.org/10.1146/annur ev-clinpsy-032511-143150.

3. Gomez R. Factor structure of parent and teacher ratings of the ODD symptoms for Malaysian primary school children. Asian J Psychiatr. 2017;25:22-6. https://doi.org/10.1016/j.ajp.2016.10.013.

4. Cavanagh M, Quinn D, Duncan D, Graham T, Balbuena L. Oppositional defiant disorder is better conceptualized as a disorder of emotional regulation. J Atten Disord. 2014. https://doi.org/10.1177/1087054713520221

\section{[Epub ahead of print]}

5. Bradshaw $C P$, Schaeffer $C M$, Petras $H$, lalongo N. Predicting negative life outcomes from early aggressive-disruptive behavior trajectories: gender differences in maladaptation across life domains. J Youth Adolesc. 2010;39(8):953-66. https://doi.org/10.1007/s10964-009-9442-8.

6. Loeber R, Burke JD, Lahey BB, Winters A, Zera M. Oppositional defiant and conduct disorder: a review of the past 10 years, part I. J Am Acad Child Adolesc Psychiatry. 2000;39(12):1468-84. https://doi.org/10.1097/00004 583-200012000-00007.

7. Gomez R, Hafetz N, Gomez RM. Oppositional defiant disorder: prevalence based on parent and teacher ratings of Malaysian primary school children. Asian J Psychiatr. 2013;6(4):299-302. https://doi.org/10.1016/j. ajp.2013.01.008.

8. Ercan ES, Kandulu R, Uslu E, Ardic UA, Yazici KU, Basay BK, Aydın C, Rohde LA. Prevalence and diagnostic stability of ADHD and ODD in Turkish children: a 4-year longitudinal study. Child Adolesc Psychiatry Ment Health. 2013;7(1):30. https://doi.org/10.1186/1753-2000-7-30.

9. Pihlakoski L, Sourander A, Aromaa M, Rautava P, Helenius H, Sillanpää M The continuity of psychopathology from early childhood to preadolescence: a prospective cohort study of 3-12-year-old children. Eur Child Adolesc Psychiatry. 2006;15(7):409-17. https://doi.org/10.1007/s0078 7-006-0548-1.

10. Park TW, Park YH, Kwon HJ, Lim MH. Association between TPH2 gene polymorphisms and attention deficit hyperactivity disorder in Korean children. Genet Test Mol Biomarkers. 2013;17(4):301-6. https://doi. org/10.1089/gtmb.2012.0376.

11. Brewer JA, Potenza MN. The neurobiology and genetics of impulse control disorders: relationships to drug addictions. Biochem Pharmacol. 2008;75(1):63-75. https://doi.org/10.1016/j.bcp.2007.06.043.

12. Coccaro EF, Lee R. Cerebrospinal fluid 5-hydroxyindolacetic acid and homovanillic acid: reciprocal relationships with impulsive aggression in human subjects. J Neural Transm. 2010;117(2):241-8. https://doi. org/10.1007/s00702-009-0359-x.

13. Marazziti D, Baroni S, Masala I, Golia F, Consoli G, Massimetti G, Picchetti M, Catena Dell'osso M, Giannaccini G. Impulsivity, gender, and the platelet serotonin transporter in healthy subjects. Neuropsychiatr Dis Treat. 2010;6:9-15.

14. Wang CH, Liu C, Cong EZ, Xu GL, Lv TT, Zhang YL, Ning QF, Wang JK, Nie HY, Li Y. Association of tryptophan hydroxylase-2 polymorphisms with oppositional defiant disorder in a Chinese Han population. Behav Brain Funct. 2016;12(1):30. https://doi.org/10.1186/s12993-016-0113-0.

15. Rydén E, Johansson C, Blennow K, Landén M. Lower CSF HVA and 5-HIAA in bipolar disorder type 1 with a history of childhood ADHD. J Neural Transm (Vienna). 2009;116(12):1667-74. https://doi.org/10.1007/s0070 2-009-0300-3.

16. Manco L, Soares A, Wasterlain SN. Association of 5-HTTLPR genotypes with antisocial behavior in response to childhood environment: a study in young adults of Portuguese origin. Psychiatry Res. 2017. https://doi. org/10.1016/j.psychres.2017.01.001 [Epub ahead of print].

17. Glick A. The role of serotonin in impulsive aggression, suicide, and homicide in adolescents and adults: a literature review. Int J Adolesc Med Health. 2015;27(2):143-50. https://doi.org/10.1515/ijamh-2015-5003.

18. Fowler T, Langley K, Rice F, van den Bree MB, Ross K, Wilkinson LS, Owen MJ, O'Donovan MC, Thapar A. Psychopathy trait scores in adolescents with childhood ADHD: the contribution of genotypes affecting MAOA, 5HTT and COMT activity. Psychiatr Genet. 2009;19(6):312-9. https://doi. org/10.1097/YPG.0b013e3283328df4. 
19. Hankin BL, Barrocas AL, Jenness J, Oppenheimer CW, Badanes LS, Abela $J R$, Young J, Smolen A. Association between 5-HTTLPR and borderline personality disorder traits among youth. Front Psychiatry. 2011;2:1-6. https://doi.org/10.3389/fpsyt.2011.00006.

20. Checknita D, Maussion G, Labonté B, Comai S, Tremblay RE, Vitaro F, Turecki N, Bertazzo A, Gobbi G, Côté G, Turecki G. Monoamine oxidase A gene promoter methylation and transcriptional downregulation in an offender population with antisocial personality disorder. Br J Psychiatry. 2015:206(3):216-22. https://doi.org/10.1192/bjp.bp.114.144964.

21. Laqua C, Zill P, Koller G, Preuss U, Soyka M. Association between the MAOA-UVNTR polymorphism and antisocial personality traits in alcoholic men. Fortschr Neurol Psychiatr. 2015;83(3):162-9. https://doi. org/10.1055/s-0034-1399249.

22. Godar SC, Fite PJ, McFarlin KM, Bortolato M. The role of monoamine oxidase $\mathrm{A}$ in aggression: current translational developments and future challenges. Prog Neuropsychopharmacol Biol Psychiatry. 2016;69:90-100, https://doi.org/10.1016/j.pnpbp.2016.01.001.

23. Ma R, Jia H, Yi F, Ming Q, Wang X, Gao Y, Yi J, Yao S. Electrophysiological responses of feedback processing are modulated by MAOA genotype in healthy male adolescents. Neurosci Lett. 2016:610:144-9. https://doi. org/10.1016/j.neulet.2015.11.009.

24. Ouellet-Morin I, Côté SM, Vitaro F, Hébert M, Carbonneau R, Lacourse É, Turecki G, Tremblay RE. Effects of the MAOA gene and levels of exposure to violence on antisocial outcomes. Br J Psychiatry. 2016;208(1):42-8. https://doi.org/10.1192/bjp.bp.114.162081.

25. Sabol SZ, Hu S, Hamer D. A functional polymorphism in the monoamine oxidase A gene promoter. Hum Genet. 1998;103:273-9.

26. Wendland JR, Martin BJ, Kruse MR, Lesch KP, Murphy DL. Simultaneous genotyping of four functional loci of human SLC6A4, with a reappraisal of 5-HTTLPR and rs25531. Mol Psychiatry. 2006;1 1(3):224-46. https://doi. org/10.1038/sj.mp.4001789.

27. Manor I, Tyano S, Mel E, Eisenberg J, Bachner-Melman R, Kotler M, Ebstein RP. Family-based and association studies of monoamine oxidase A and attention deficit hyperactivity disorder (ADHD): preferential transmission of the long promoter-region repeat and its association with impaired performance on a continuous performance test (TOVA). Mol Psychiatry. 2002;7(6):626-32. https://doi.org/10.1038/sj.mp.4001037.

28. Deckert J, Catalano M, Syagailo YV, Bosi M, Okladnova O, Di Bella D, Nöthen MM, Maffei P, Franke P, Fritze J, Maier W. Excess of high activity monoamine oxidase A gene promoter alleles in female patients with panic disorder. Hum Mol Genet. 1999;8(4):621-4.

29. Wang J, Shete S. Using both cases and controls for testing hardyweinberg proportions in a genetic association study. Hum Hered. 2010;69(3):212-8. https://doi.org/10.1159/000289597.

30. Courtet P, Baud P, Abbar M, Boulenger JP, Castelnau D, Mouthon D, Malafosse A, Buresi C. Association between violent suicidal behavior and the low activity allele of the serotonin transporter gene. Mol Psychiatry. 2001;6(3):338-41. https://doi.org/10.1038/sj.mp.4000856.

31. van der Meer $D$, Hartman $C A$, Pruim RH, Mennes M, Heslenfeld D, Oosterlaan J, Faraone SV, Franke B, Buitelaar JK. The interaction between 5-HTTLPR and stress exposure influences connectivity of the executive control and default mode brain networks. Brain Imaging Behav. 2016. https://doi.org/10.1007/s11682-016-9633-3 [Epub ahead of print]

32. Simons JS, Simons RM, O'Brien C, Stoltenberg SF, Keith JA, Hudson JA. PTSD, alcohol dependence, and conduct problems: distinct pathways via lability and disinhibition. Addict Behav. 2017;64:185-93. https://doi. org/10.1016/j.addbeh.2016.08.044.

33. Liao DL, Hong CJ, Shih HL, Tsai SJ. Possible association between serotonin transporter promoter region polymorphism and extremely violent crime in Chinese males. Neuropsychobiology. 2004;50(4):284-7. https://doi. org/10.1159/000080953.
34. Sukonick DL, Pollock BG, Sweet RA, Mulsant BH, Rosen J, Klunk WE, Kastango KB, DeKosky ST, Ferrell RE. The $5-H T T P R * S /{ }^{*} L$ polymorphism and aggressive behavior in Alzheimer disease. Arch Neurol. 2001;58(9):1425-8.

35. Contini V, Marques FZ, Garcia CE, Hutz MH, Bau CH. MAOA-uVNTR polymorphism in a Brazilian sample: further support for the association with impulsive behaviors and alcohol dependence. Am J Med Genet B Neuropsychiatr Genet. 2006;41B(3):305-8. https://doi.org/10.1002/ ajmg.b.30290.

36. Zhang Y, Ming $Q$, Wang $X$, Yao $S$. The interactive effect of the MAOA-VNTR genotype and childhood abuse on aggressive behaviors in Chinese male adolescents. Psychiatr Genet. 2016;26(3):117-23. https://doi.org/10.1097/ ypg.0000000000000125.

37. Hohmann S, Zohsel K, Buchmann AF, Blomeyer D, Holz N, Boecker-Schlier $\mathrm{R}$, Jennen-Steinmetz C, Rietschel M, Witt SH. Interacting effect of MAOA genotype and maternal prenatal smoking on aggressive behavior in young adulthood. J Neural Transm (Vienna). 2016;123(8):885-94. https:// doi.org/10.1007/s00702-016-1582-X

38. Lung FW, Tzeng DS, Huang MF, Lee MB. Association of the MAOA promoter uVNTR polymorphism with suicide attempts in patients with major depressive disorder. BMC Med Genet. 2011:12:74. https://doi. org/10.1186/1471-2350-12-74.

39. Caspi A, McClay J, Moffitt TE, Mill J, Martin J, Craig IW, Taylor A, Poulton R. Role of genotype in the cycle of violence in maltreated children. Science. 2002;297(5582):851-4. https://doi.org/10.1126/science.1072290.

40. Galán CA, Choe DE, Forbes EE, Shaw DS. The interaction between monoamine oxidase $A$ and punitive discipline in the development of antisocial behavior: mediation by maladaptive social information processing. Dev Psychopathol. 2016. https://doi.org/10.1017/s0954579416001279 [Epub ahead of print].

41. Chester DS, DeWall CN, Derefinko KJ, Estus S, Peters JR, Lynam DR, Jiang Y. Monoamine oxidase A (MAOA) genotype predicts greater aggression through impulsive reactivity to negative affect. Behav Brain Res. 2015;283:97-101. https://doi.org/10.1016/j.bbr.2015.01.034.

42. Manuck SB, Flory JD, Muldoon MF, Ferrell RE. Central nervous system serotonergic responsivity and aggressive disposition in men. Physiol Behav. 2002;77(4-5):705-9.

43. Zammit S, Jones G, Jones SJ, Norton N, Sanders RD, Milham C, McCarthy GM, Jones LA, Cardno AG, Gray M, Murphy KC. Polymorphisms in the $M A O A, M A O B$, and COMT genes and aggressive behavior in schizophrenia. Am J Med Genet B Neuropsychiatr Genet. 2004;128B(1):19-20. https ://doi.org/10.1002/ajmg.b.30021.

44. Koller G, Bondy B, Preuss UW, Bottlender M, Soyka M. No association between a polymorphism in the promoter region of the MAOA gene with antisocial personality traits in alcoholics. Alcohol Alcohol. 2003;38(1):31-4.

45. Schlüter T, Winz O, Henkel K, Eggermann T, Mohammadkhani-Shali S, Dietrich C, Heinzel A, Decker M, Cumming P. MAOA-VNTR polymorphism modulates context-dependent dopamine release and aggressive behavior in males. Neuroimage. 2016;125:378-85. https://doi.org/10.1016/j. neuroimage.2015.10.031.

Ready to submit your research? Choose BMC and benefit from:

- fast, convenient online submission

- thorough peer review by experienced researchers in your field

- rapid publication on acceptance

- support for research data, including large and complex data types

- gold Open Access which fosters wider collaboration and increased citations

- maximum visibility for your research: over 100M website views per year

At BMC, research is always in progress.

Learn more biomedcentral.com/submissions 